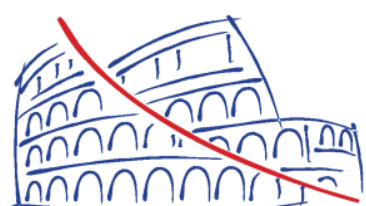

TIHE SECOND

WORLD

LANDSLIDE FORUM
Hans-Balder Havenith ${ }^{(1)}$, Kanatbek Abdrakhmatov ${ }^{(2)}$, Isakbek Torgoev $^{(3)}$, Anatoly Ischuk ${ }^{(4)}$, Alexander Strom ${ }^{(5)}$, Erik Bystrický( ${ }^{(6)}$, Andrej Cipciar ${ }^{(6)}$

\section{Earthquakes, landslides, dams and reservoirs in the Tien Shan, Central Asia}

(1) University of Liege, Department of Geology - B18, Liege, 4000, Belgium, +32 43669316

(2) Kyrgyz Institute of Seismology, Bishkek, Kyrgyzstan

(3) Institute of Geomechanics and development of Subsoil, Bishkek, Kyrgyzstan

(4) Institute of Earthquake Engineering and Seismology, Dushanbe, Tajikistan

(5) Institute of the Geospheres Dynamics, Russian Academy of Sciences, Moscow, Russia

(6) Seismology Department, Geophysical Institute, Bratislava, Slovak Republic

\begin{abstract}
This paper presents an overview of seismic and mass movement hazards affecting major Hydropowerplants (HPP) and ongoing dam projects in the mountain regions of Central Asia. HPP cascades are located along the Naryn River in the Kyrgyz Republic and the VakhshSurkhob valley fault zone in Tajikistan. The latter region hosting the presently and future tallest man-made dams of the world is very prone to earthquakes and various types of slope instabilities. The Naryn Valley hosting several dam sites is marked by the presence of ancient rockslides and a dense network of seismically active faults. In December 2009, Kyrgyz, Russian, Slovak and Belgian teams have monitored seismic ground motions and displacements induced by the blasting of a slope on the Kambarata 2 site producing a $35 \mathrm{~m}$-high blockage on the Naryn River. This work is part of a NATO Science for Peace and Security project on landslide dam hazards in the Tien Shan.
\end{abstract}

Keywords landslide and man-made dams, seismic hazard, Tien Shan

\section{Introduction}

Tajikistan and Kyrgyzstan have an enormous potential to exploit hydroelectric power. However, most of the territory of these two countries is mountainous with very high seismicity (Figure 1), active slope failure processes and phenomena such as landslides, rock falls, and debris flows. These additional processes should be taken into account as part of the seismic hazard and risk assessment for hydroelectric dams in the Vakhsh and Naryn River valleys (Figure 1).

The Vakhsh-Surkhob valley fault zone in Tajikistan is hosting the presently tallest man-made dam of the world (Nurek dam, height of $300 \mathrm{~m}$ ) as well as the construction site of the future tallest dam of the world (Rogun dam, height of $335 \mathrm{~m}$ ). The very high seismic hazard of the future Rogun reservoir region is exemplified by the occurrence of the disastrous $\mathrm{Ms}=7.4$ Khait earthquake in 1949, which had triggered a series of catastrophic mass movements, killing more than 5000 people (Gubin, 1960). Our seismic hazard computations applied to the Tien Shan cover the northern part of the region - for which more than $0.5 \mathrm{~g}$ had been predicted considering a return period of 475 years (Abdrakhmatov et al. 2003). The future filling of the Rogun reservoir will also be of interest from a seismological point of view since it is expected that it will generate thousands of $\mathrm{M}=\mathrm{O}-5$ earthquakes, just as the filling of the Nurek reservoir did in the 7os (Simpson and Negmatullaev 1981). This region is also very prone to various types of slope instabilities: earth flows in soft deposits (mostly made of loess), rock falls and debris flows; those are likely to be enhanced by the rise of the groundwater pressures associated to the filling and/or by the induced/natural seismicity.

The Kambarata HPP-chain project is located along the Central Tien Shan tectonic zone (Naryn Valley, Kyrgyz Republic). It includes the existing Toktogul dam, Kambarata 2 dam under construction and the future Kambarata 1 dam site. This region is marked by the presence of ancient rockslides and a dense network of seismically active faults. The blasting of a slope on the Kambarata 2 site was monitored in the frame of a NATO Science for Peace and Security project on landslide dam hazards in the Tien Shan (see also Torgoev et al., same volume). The blast had produced a $35 \mathrm{~m}$-high blockage on the Naryn River, the main part of the final dam (design height of 50-6o m). Seismic ground motions and slope movements have been recorded on adjacent slopes. At closest sites, the ground shaking exceeded $1 \mathrm{~g}$ and a series of shallow slope failures could be observed. Those had also been monitored by extensometer measurements. The neighboring slopes are still being surveyed to detect possible post-blast instabilities. First results of the seismological and geotechnical monitoring will be shown. 


\section{Probabilistic PGA map for the Tien Shan}

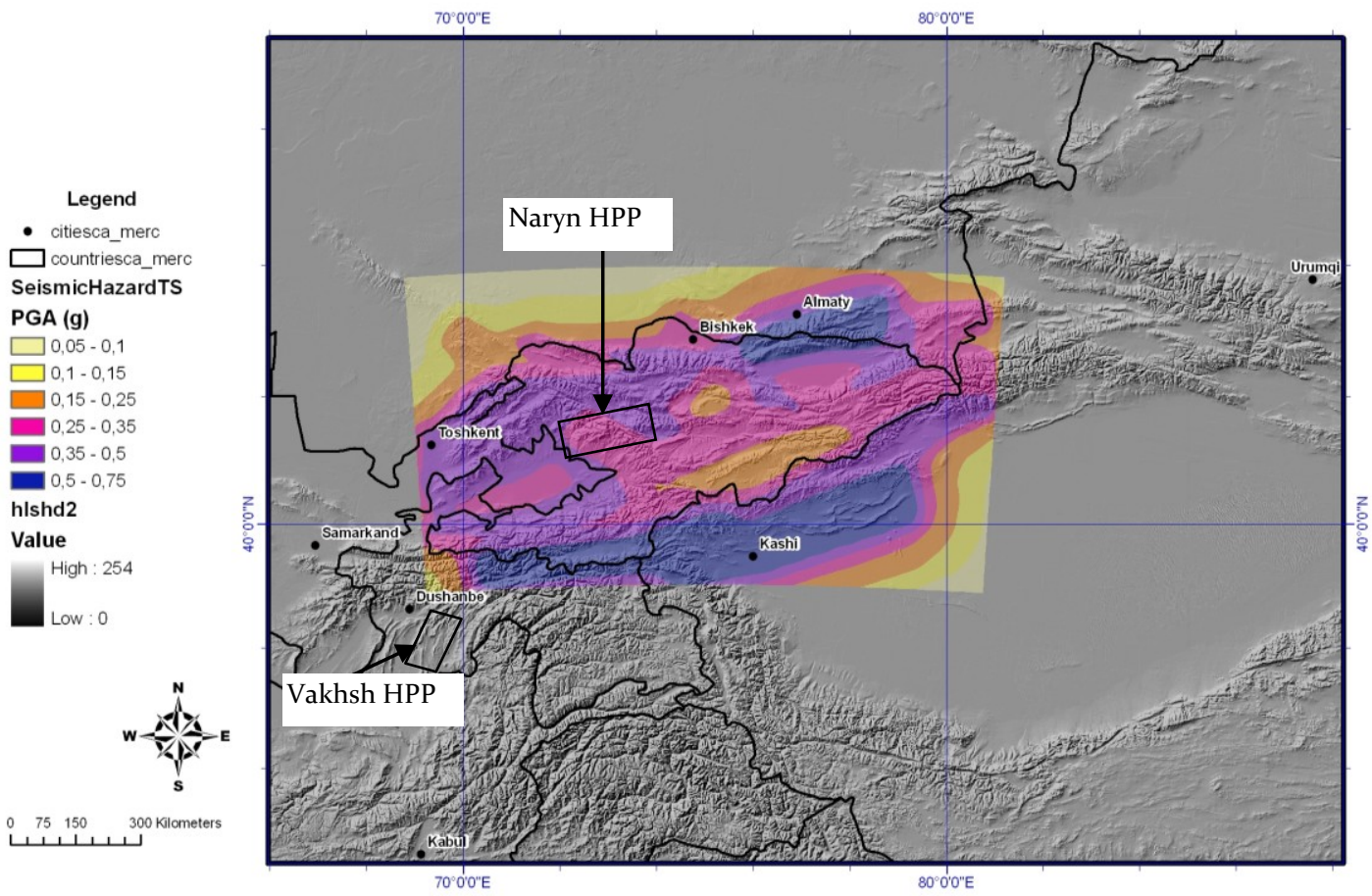

Figure 1 Probabilistic seismic hazard map of the Kyrgyz Tien Shan (modified from Abdrakhmatov et al., 2003) with location of the HPP cascades in Tajikistan and Kyrgyzstan.

\section{The Vakhsh River HPP cascade}

The Vakhsh River valley offers the best opportunity in Tajikistan for hydroelectric power, and there are already a series of HPPs in operation or under construction. These dams include Perepadnaya, Golovnaya, Sangtuda-2 (7o m dam under construction now), Sangtuda-1 (70 m dam), Baipaza (70 m dam), Nurek (300 m dam), and Rogun HPP which will be the highest dam in the world ( $335 \mathrm{~m}$ ) when construction is completed. The two largest dams (Nurek and Rogun) are located in the most seismically active zone in Tajikistan, and earthquakes with magnitudes greater than 7 are possible. Brief summaries of the two largest dams are given below (Ischuk et al., 2008).

\section{Nurek HPP}

The Nurek HPP has a 3,00o MW capacity and is currently the biggest HPP in Central Asia. It is located in the middle part of the Vakhsh River valley. The capital of Tajikistan, Dushanbe, lies $75 \mathrm{~km}$ to the northwest of Nurek dam. The construction of the Nurek HPP started in 1961 and the first hydroelectric generator with $300 \mathrm{MW}$ power began operation in 1972. The rock-fill dam has a maximum height of $300 \mathrm{~m}$ and its volume is 54.2 million $\mathrm{m}^{3}$. Depending on the season, the reservoir formed by the Nurek dam can be up to $70 \mathrm{~km}$ in length. The surface area of the reservoir is $98 \mathrm{~km}^{2}$, and the annual water level drawdown is $53 \mathrm{~m}$.

\section{Rogun HPP}

The Rogun HPP is being constructed on the Vakhsh River approximately $70 \mathrm{~km}$ upstream from the Nurek Dam near the settlement of Obigarm and the town of Rogun. The Rogun dam is being built primarily for irrigation and hydropower. The main parameters of the Rogun HPP include: a planned production capacity of 3,600 MW; a design height of the dam of $335 \mathrm{~m}$; a total reservoir volume of $13.3 \mathrm{~km}^{3}$.

The preliminary preparation of the Rogun HPP construction site began in October 1976 and basic construction began in March 1981.

Construction of the Rogun HPP stopped several times and, in particular, during the civil war in Tajikistan. In 2006 the Government of Tajikistan decided to continue the construction of the Rogun dam and power station. When the Rogun HPP becomes operational, Tajikistan will be capable of meeting all of its own electrical power needs as well as exporting power to other countries. The economic importance of Rogun dam to Tajikistan is very high. The need to monitor the geophysical processes in the vicinity of Rogun dam is necessary as shown by the events of May 1993 described below.

\section{Mass movements and other hazards along the HPP}

The following case histories exemplify the landslide risk around the dams (based on Ischuk et al. 2008).

During the new construction phase of the Rogun dam started in the 9o's, a debris flow of one million cubic 
meters occurred near the downstream face of the diversion dam, blocking the Vakhsh River. The river level rose $13.5 \mathrm{~m}$. The resulting flood topped the diversion dam, destroying the main portion of the dam on May 9, 1993.

A more recent disaster was caused by the Baipaza landslide located $4.5 \mathrm{~km}$ downstream from the Baipaza HPP (downstrem from Nurek dam). The first displacement of this landslide was in 1968 and it partially blocked the Vakhsh River, before design and construction of the Baipaza HPP. In 1969 the volume of the Baipaza landslide was assessed to be 20-25 million $\mathrm{m}^{3}$. In May 1992, the Baipaza landslide moved again as a result of heavy rains, and the Vakhsh River was dammed. After the March 3, 2002, Hindu Kush earthquake (magnitude $\mathrm{Mw}=7.4$, with an epicenter located in Afghanistan at a distance $250 \mathrm{~km}$ from the Baipaza site, and with an intensity of shaking of 6 degrees on EMS-98 scale), this landslide started to move and partially blocked again the Vakhsh River (Figure 2). As a result, the Baipaza HPP could not operate at a normal level for one month. The use of high explosives was required to clear the river bed after this landslide. The next significant landslide movement could lead to a catastrophe if a large lake formed: the inundation could stop the normal operation of Nurek and Baipaz HPPs; an outburst flood could destroy the downstream Golovnaya and Perepadnaya HPPs. Related hazards are now being assessed in the frame of a new NATO SFP project coordinated by American (IRIS DMC) and Tajik (Geophysical Survey) partners.

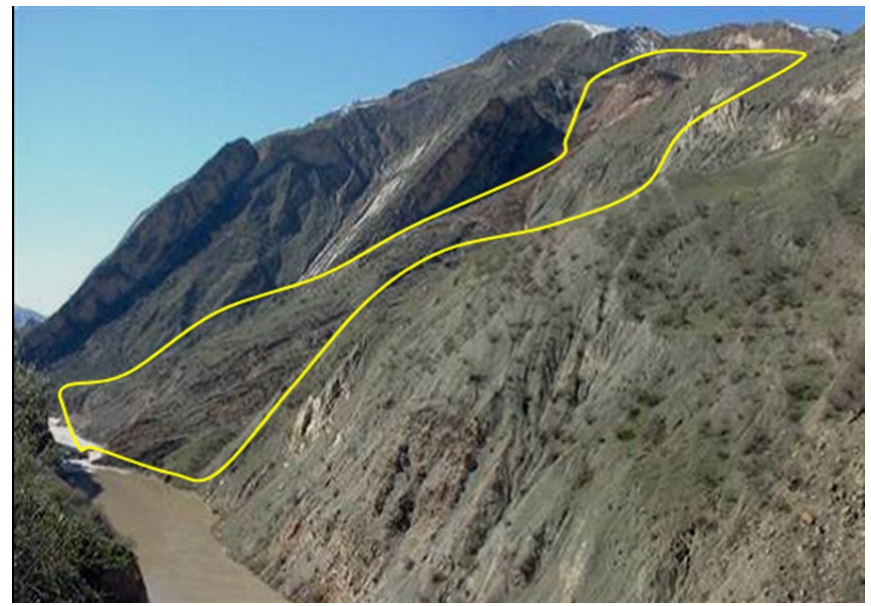

Figure 2 Baipaza landslide dam triggered by the 2002 Hindukush earthquake - the mass movement is outlined in yellow.

The Rogun reservoir area is particularly prone to debris flows and various induced earthquake hazards. The upper part of the future reservoir is located close to the epicentral zone of the 1949 Khait earthquake (partly shown in Fig. 3). This earthquake triggered a rock avalanche that had buried the villages of Khait and Kusurak with thousands of inhabitants; however, the exact number of fatalities will never be known.
This rock avalanche had been triggered at an altitude of about $2950 \mathrm{~m}$ and travelled more than $6 \mathrm{~km}$ (blue arrows in Fig. 3 indicate related movements) before reaching the inhabited valley at an altitude of $1550 \mathrm{~m}$. The total volume is about $4010^{6} \mathrm{~m}^{3}$. A significant part of the mass movement was made of loess, which probably contributed to the mobility of the initial rockslide. In the Yasman valley opposite to the Khait rock avalanche, massive loess earth-flows are believed to have buried about 20 villages. According to our observations, such a massive flow could only develop in several steps (see figure 3): first, coseismic failure of the shallow loess cover on steep slopes (small orange arows); second, confluence of loess material in small N-S oriented tributary valleys (larger orange arrows) and formation of dams (orange ellipses) and small reservoirs (small light blue ellipses) in the main E-W oriented valley; third, failure of several formed dams (domino effect) and development of the massive earthflow (long orange and light blue lines and arrows). In total, the Khait rock avalanche and loess earth-flows are likely to have killed more than 5000 people during the 1949 event.

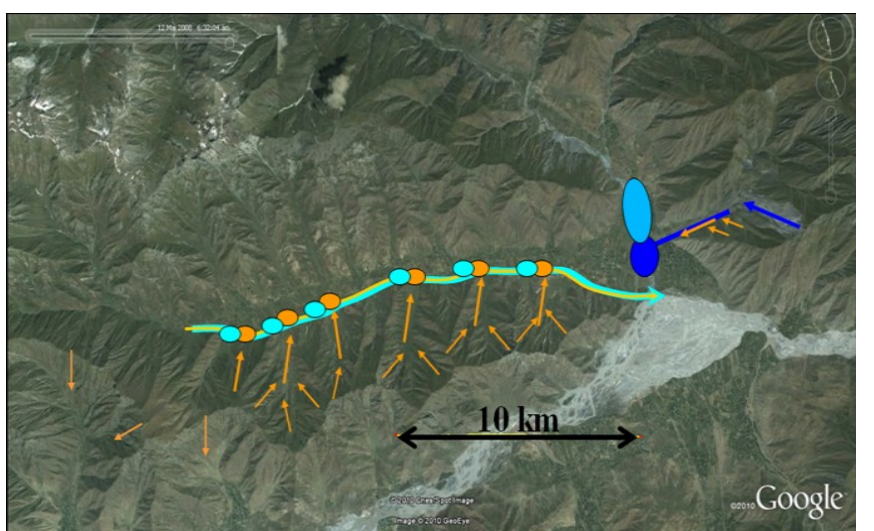

Figure 3 Epicentral zone of the M=7.4 Khait earthquake in 1949 with location of the Khait rock avalanche (on the right movements marked by dark blue lines) and the Yasman earthflow (left and central part - loess movement in orange, earthflow in light blue). Temporary reservoirs indicated by light blue ellipses.

\section{Naryn HPP projects and rockslides}

Several large hydropower projects are implemented and planned now in this region: the Kambarata-1 and Kambarata-2 dams in the Naryn River valley upstream of the Toktogul Reservoir.

The Kambarata-2 project is currently under construction. It includes a $60 \mathrm{~m}$ high blast-fill dam that was constructed in 2009 using about 3000 tons of explosives (producing an initial $35 \mathrm{~m}$ high blockage). Its finally $50 \mathrm{~m}$ deep and $9 \mathrm{~km}$ long reservoir is located in a tectonically active and landslide-prone zone. The Kambarata-1 Project is now at the feasibility stage. Seismic and mass movement hazards along the Naryn HPP are being assessed in the frame of the present NATO SFP project LADATSHA. 


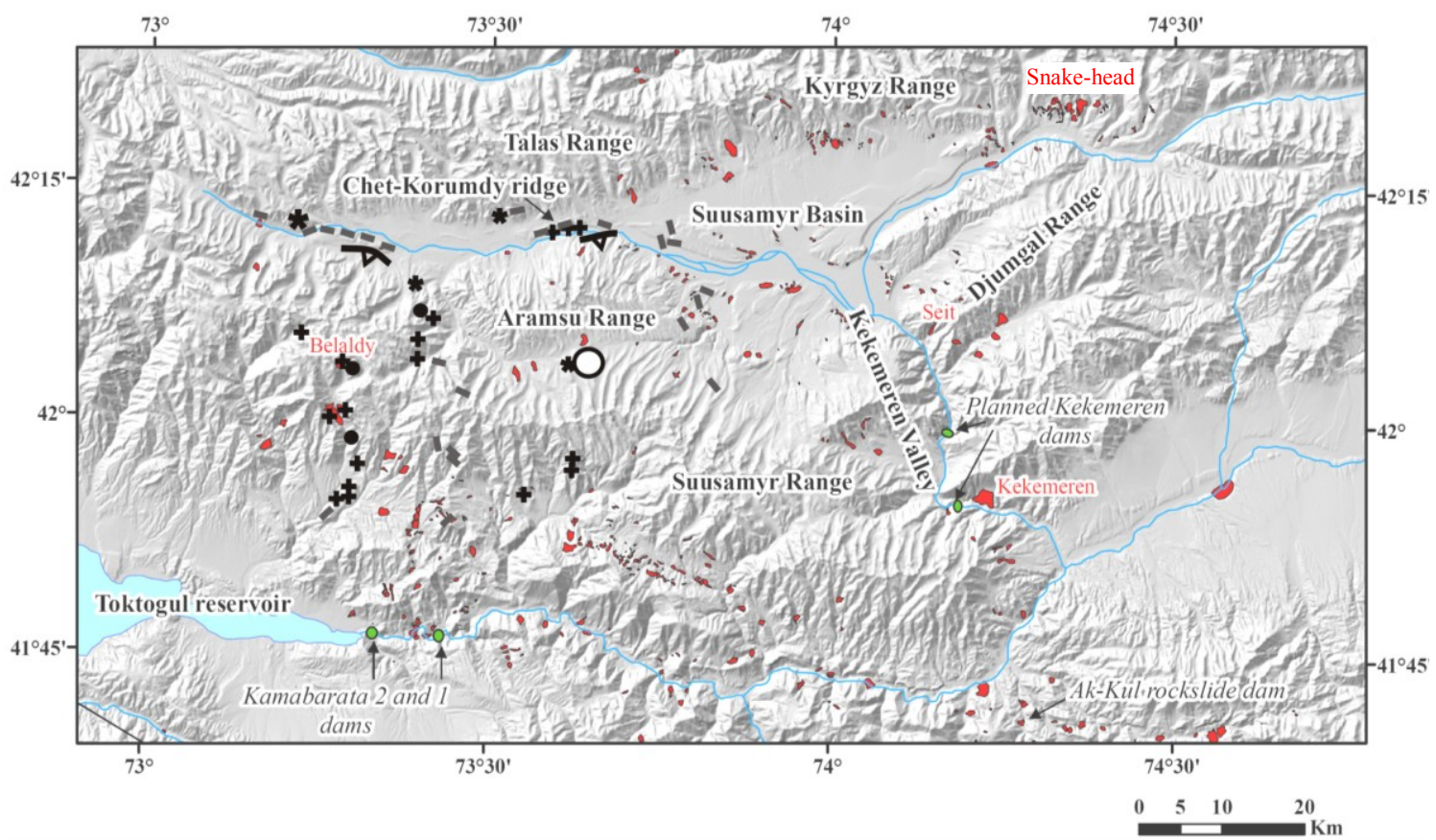

Figure 4 Map of all detected landslides in the Suusamyr region (red) and ground failures triggered by the Suusamyr earthquake (modified from Korjenkov et al. 2004 - circle: M=7.3, 1992 epicentre; black lines with triangle: 1992 fault scarps; crosses: rockslides and landslides; stars: mud eruptions; grey bars: ground and slope fractures, black dots: rock falls).

A
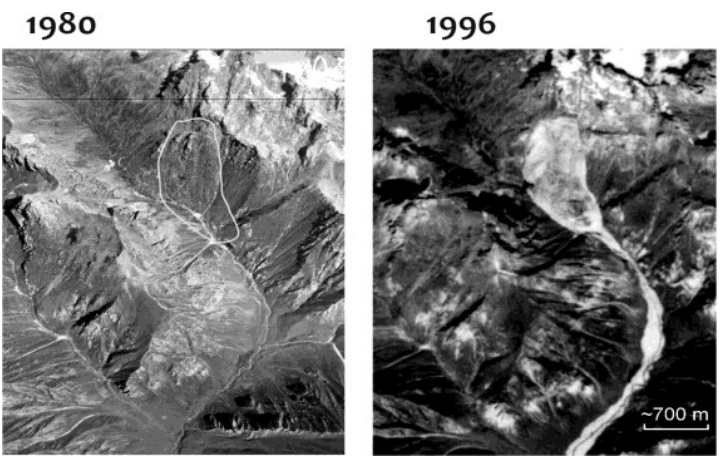

B

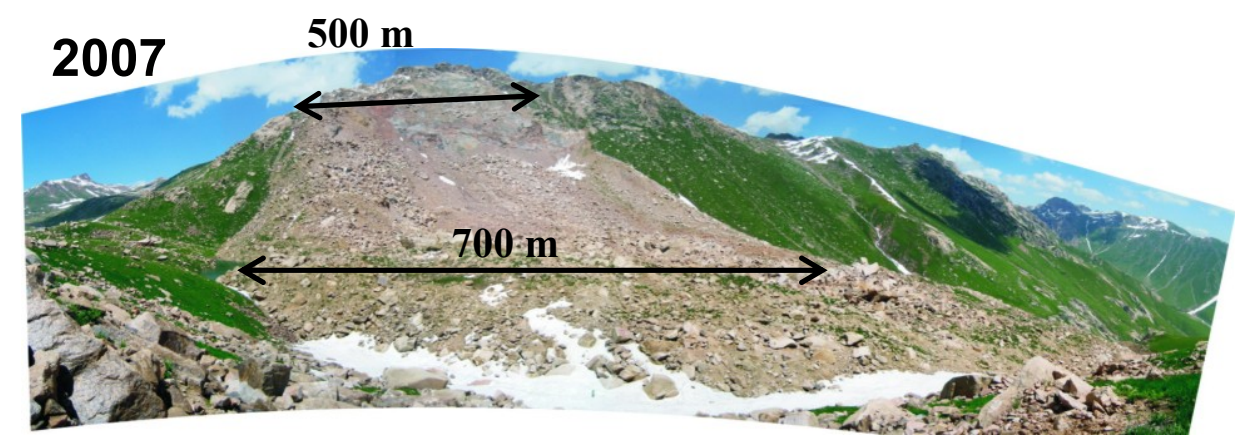

Figure 5 Belaldy rock avalanche. a) Aerial photographs of the site acquired in 1980 (left), before the 1992 Suusamyr earthquake and in 1996 (right), after the earthquake. b) Photograph of the rock avalanche (scarp, behind, and dam, in front) in 2007.

\section{Hazards in the Kambarata area}

By now 200 rockslides and even more potentially unstable slopes have been identified close to the reservoir areas (see figure 4; see also Strom et al. 2010). The largest recent rock avalanche forming a dam in the Tien Shan was triggered by the Suusamyr earthquake in August 1992 along the upper reaches of the Belaldy River (figure 5).
The initial rockslide with a volume of more than $4010^{6}$ $\mathrm{m}^{3}$ had killed a shepherd's family and a flock of sheep.

Within a few months, two small lakes had formed behind the dam. The rising water level in the lakes and the increased groundwater pressure within the mass movement gradually weakened the dam. In summer 1993, less than a year after formation, the dam partly failed. From this rupture, a debris flow developed (see title page) which significantly damaged villages along the 
Belaldy River down to the Toktogul Reservoir. Bridges and dwellings located on lower terraces were destroyed and ten people were killed. The Bishkek-Osh highway was also partly destroyed, causing an interrupted traffic for several days along this principal road between these two main towns of the Kyrgyz Republic.

\section{Acknowledgments}

This activity was provided within the frame of NATO SfP983289 project "Prevention of Landslide Dam Disasters in the Tien Shan, Kyrgyz Republic".

\section{References}

Abdrakhmatov K, Havenith HB, Delvaux D, Jongmans D, Trefois $P$ (2003) Probabilistic PGA and Arias Intensity maps of Kyrgyzstan (Central Asia). Journal of Seismology. 7: 203-220.

GUBIN, IE (1960) Patterns of seismic manifestations of the Tajikistan territory (geology and seismicity). Moscow, Academy of Sciences of USSR Publishing House (in Russian).

Ischuk AR, Babaev A, Negmatoullaev SK (2008) Seismic conditions of the territory of Tajikistan. Published by TIEES. 92p.

Korjenkov AM, Mamyrov E, Omuraliev M, Kovalenko VA, Usmanov SF (2004) Rock Avalanches and Landslides Formed in Result of Strong Suusamyr $(1992, M=7,4)$ Earthquake in the Northern Tien Shan. Test Structures for Mapping of Paleoseismic Deformations by Satellite Images. Proceedings of the High Mountain Remote Sensing Cartography VII (HMRSC VII), Buchroithner MF., Institute for Cartography of the Dresden University of Technology. Kartographische Bausteine, Band 23, Dresden, $19 \mathrm{p}$.

Simpson D. W. Negmatullaev S. K. (1981). Induced seismicity at Nurek Reservoir, Tadjikistan, USSR. BSSA, 71(5), 1561-1586.

Strom, A. (2010) Landslide dams in Central Asia region. Journal of the Japan Landslide Society. 47(6): 1-16. 